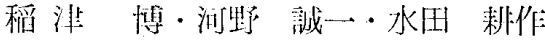

篠原 悌五・岩切 国雄・猪分倉政盛

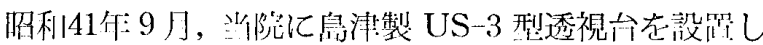
た。

しかし装置付属の圧迫筒では，

(1) 像が逃げやすい.

(2) 圧迫像の出現範冊がせまい.

(3) 力の配分がむつかしい。

（4）圧迫の強弱の範畔がせまい。

(5) 圧迫操作任雨手起必要とする。

（6）利用線錐の中心しか压迫できない.

等の欠点があり，思うような圧迫像を得られなかった。

そこで圧迫筒の形状㧍よび機構を次のように改良した。

(1) 先端を平らにしその直径を $4 \mathrm{~cm}$ と $6 \mathrm{~cm}$ としその 先に $0.5 \mathrm{~cm}$ のスポンジを取り付けた.

(2) $4 \mathrm{~cm}$ と $6 \mathrm{~cm}$ のむのは交換可能とした.

(3) 検者の肴望する位置で圧迫简を停止させるととが できるようにした。

この結果，前記の欠点は大部分改良され，良好な結果 を得ている.

この改良形圧迫筒を使用した．昭和43年 1 月かから 6 月 までの 6 力月間の透視診断で所見のある例の, 压迫効果 について検討した。

調査の内容は, 前壁レリーフ像, 立位充盈像, 機械仁 上る圧迫像, 2 重造影, 腹臥位充盈像, 手に上る圧迫が ぞうしてあ必要であったあのの6つの手技について，手 技を行なってないむの直接所兌の見られるむの, 変形等 の間接所見の見られるすの，所見の見られないすのの 4 段階に分故て調查した。

胃癌，胃ポリープ，胃漬瘍，十二指腸潰瘍共改造した 圧迫筒は手による圧迫が必要のない程の好結果を示し た。

\section{XTV の一ケ年間の使用状況について}

\section{国家公務員共済組合連合会 稲田登戸病院} 中野千代治 他

当院において過去一力年間使用した $\mathrm{S}$ 社 $\mathrm{X}$ 線テレビの 使用例の胃腸 透視 2,258例，15,897 枚撮影を始匃気管支 造影, 整形術, 卵管, 動脈, 腎孟, 胆囊造影その他, 手 術等広範囲の使用例を挙げ，またとれによる故障の部で はカセッテ送りエレベーターの故障がもっとも多く細部 に区分して，その他，機械全般の故障を10項目に付きお

のおのの故障を生じてより, 修理完了までの期間と, これの対策等を述へ，また当院において改造を試みる具 合の 6 項目と，将来改良を望む箇所としては透視台の水

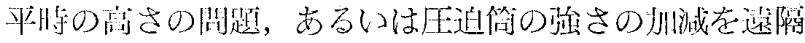
操作により，機械的に変わることのできる装置を望み， 絬諭として使用頻度の淌きX線テレビの紼部にわたる改 善と, 故䧑箈听の早期発見と, 修理の迎速化を望んだ次 第である。

\section{質問}

分割用カセッテが高圧撮影時に逃げるということは

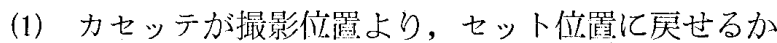

（2）または，カセッテ自において分制時比上下移動す るのか，むし分割用上下移動に故障が生じるとき 原因としてカセッテ側面の移動用カムがあり，こ の部分の故障に関係があるのか，お伺いします。

(京都 上地)

\section{答}

電源電圧の降下による各りレーの動作不良がある。

これは発表中部しく申し上げました。

\section{X線テレビジョン画質の検討（第 1 報）量子雑音 の影響とその対策}

東邦大学医学部付属病院 中央放射線部 泉 重 光 - 板垣 勝義 - 小堺加智夫

X線 TV で厚い被写体を観察した場合, 䧱音のため, いちじるしく画質を低下させるととがある．

この原因は主として入射 $\mathrm{X}$ 線量子の統計的ゆらぎによ るあのであり，その割合はポアソン分布にしたがうとい われている。

しかし実際にX線 TV 画面の雑音には時として大き い塊状のものがあり，比較的ゆるやかな動きをする。乙 のような現象は量子のむののゆらぎだけによるむのでな く，撮像管ターゲット面における映像蓄積の時間的因子 蓄積像の漏洩等のための雑音像の集合あるいは干渉によ る別個のパターンの形成によるむのではないかと考えら れる。

ここでわれわれは撮像管ターゲットの映像蓄積をでく 短時間におてなわせた後，通常の走查を抢てなら方法， すなわちビデオ・ブランキングパルス法に撮像をおこな い，従来の方法によるものとの比較をしたので報告す る.

実験は単相全波整流佂一次制御シネパルス装置を付設 し管電流波高值 $15 \mathrm{~mA}$ ，パルス幅 $2 \mathrm{mS}$ に設定したすの と，乙れと同一照射線量の通常透視 $2.2 \mathrm{~mA}$ につてお となった。

その結果，TV 画面の X線量子ゆらぎに寄因する雑音 をある程度低減させ粒状性が问上した。京た同時に対照 度の向上むみとめられた。 